\title{
Seasonal dynamics in an intertidal mudflat: the case of a complex trematode life cycle
}

\author{
A. Studer*, R. Poulin \\ Department of Zoology, University of Otago, PO Box 56, Dunedin 9054, New Zealand
}

\begin{abstract}
Seasonal fluctuations of host densities and environmental factors are common in many ecosystems and have consequences for biotic interactions, such as the transmission of parasites and pathogens. Here, we investigated seasonal patterns in all host stages associated with the complex life cycle of the intertidal trematode Maritrema novaezealandensis on a mudflat where this parasite's prevalence is known to be high (Lower Portobello Bay, Otago Harbour, New Zealand). The first intermediate snail host Zeacumantus subcarinatus, a key second intermediate crustacean host, the amphipod Paracalliope novizealandiae, and definitive bird hosts were included in the study. The density (snails, amphipods), abundance (birds), prevalence, i.e. percentage of infected individuals, and infection intensity (snails, amphipods) of the studied organisms were assessed. Furthermore, temperature was recorded in tide pools, where transmission mainly occurs, over a 1 yr period. Overall, the trematode prevalence in snail hosts was $64.5 \%$, with $88.4 \%$ of infected snails harbouring M. novaezealandensis. There was a strong seasonal signal in prevalence and infection intensity in second intermediate amphipod hosts, with peaks for both parameters in summer (over $90 \%$ infected; infection intensity: 1 to 202 parasites per amphipod). This peak coincided with the highest abundance of definitive bird hosts and of small and still uninfected snails present on the mudflat. Our observations indicate that all of the transmission events necessary to complete the complex life cycle of this parasite primarily occur during warmer months.
\end{abstract}

KEY WORDS: Seasonality · Parasite transmission · Host-parasite interactions · Temperature • Maritrema novaezealandensis · Paracalliope novizealandiae $\cdot$ Zeacumantus subcarinatus

\section{INTRODUCTION}

Climatic and seasonal fluctuations in environmental factors govern many processes in nature, including patterns of diseases and parasitism (e.g. Mouritsen \& Poulin 2002a, Cattadori et al. 2005, Kim et al. 2005, Altizer et al. 2006). The role of seasonality is comparatively well explored in terms of the dynamics of infectious diseases, with a multitude of environmental drivers, including temperature and host availability, capable of generating periodic changes in hosts and pathogens (e.g. Altizer et al. 2006). However, environmental changes caused by climate change as well as natural climate oscillations (e.g. El Niño Southern Oscillation) are bound to alter seasonality in ways that will also influence the transmission of pathogens and parasites and, as a consequence, their impact on host populations (e.g. Harvell et al. 2002, Kutz et al. 2005). Therefore, a better understanding of the seasonal dynamics of host-parasite systems under current conditions may facilitate more realistic assessments of the potential consequences of predicted changes.

Temporal variations in parasite-related parameters appear to be particularly common in aquatic ecosystems exposed to seasonal variation (Shaw \& Dobson 
1995, Wilson et al. 2002). In intertidal ecosystems, the extent of environmental fluctuations is inherently pronounced. Trematode parasites are very common and highly influential components of these ecosystems and usually have complex life cycles involving several members of an intertidal community. Trematodes have been shown to play crucial roles in host population dynamics as well as community and food web structures (e.g. Lauckner 1984, Sousa 1991, Mouritsen \& Poulin 2002b, Fredensborg et al. 2005, Thompson et al. 2005, Wood et al. 2007, Mouritsen \& Poulin 2010), and they constitute a considerable and highly underestimated amount of biomass in natural systems (Kuris et al. 2008).

Infection levels of trematodes in intertidal host populations substantially differ not only spatially (e.g. Smith 2001, Kube et al. 2002a, Latham \& Poulin 2003, Hechinger \& Lafferty 2005, Byers et al. 2008) but also temporally (e.g. Hughes \& Answer 1982, Lauckner 1987, Meißner \& Bick 1997, Mouritsen et al. 1997, Al-Kandari et al. 2000, Kube et al. 2002b, Jensen et al. 2004, Al-Kandari et al. 2007). Many aspects of the transmission of trematodes are influenced by temperature, and thus, seasonal changes in temperature are bound to affect transmission dynamics (e.g. Sindermann \& Farrin 1962, Mouritsen \& Jensen 1997, Fingerut et al. 2003). Besides changes in environmental temperatures, changes regarding the hosts are also important. For example, reproduction, recruitment, parasite-induced mortality and/or increased predation pressure can influence the density of host populations, such as amphipods (e.g. Mouritsen et al. 1997). Several studies have aimed to link both spatial and temporal variation in the infection levels of intermediate hosts to the occurrence or abundance of the final host, in particular birds (e.g. Fredensborg et al. 2006, Smith 2007, Byers et al. 2008). Mouritsen et al. (1997) and Jensen et al. (2004) described the phenology of trematodes in both intermediate host populations (i.e. snail first intermediate and crustacean second intermediate hosts) and linked the temporal occurrence of migratory birds as final hosts to the patterns observed. However, no study has to our knowledge simultaneously assessed all of the host steps necessary to complete a complex trematode life cycle or coupled this assessment with an investigation of the relevant thermal microhabitat conditions to understand seasonal changes in both the host populations and the parasite population, which are exposed to a common fluctuating environment.

We used the intertidal microphallid trematode Maritrema novaezealandensis Martorelli et al., 2004
(Digenea, Microphallidae) and all of the transmission steps associated with its complex life cycle as a model system: the first intermediate host, the mudsnail Zeacumantus subcarinatus Sowerby, 1855 (Prosobranchia, Batillariidae); a second intermediate crustacean host, the amphipod Paracalliope novizealandiae Dana, 1853 (Amphipoda, Paracalliopiidae); and definitive bird hosts (confirmed and suspected species). Z. subcarinatus snails acquire infections by ingesting parasite eggs while foraging on the mudflats. Within a snail, miracidia hatch from eggs and develop into sporocysts. These structures replace the snail's gonads, eventually leading to the castration of the host and reducing the reproductive potential of an affected snail population. Within the sporocysts, large numbers of cercariae are produced asexually. In tide pools, these cercariae emerge from snails under optimal conditions for transmission. The cercariae are then directly exposed to and influenced by the environment during transmission to a second intermediate crustacean host. The transmission process from snails to, for example, amphipods is particularly sensitive to temperature: transmission pressure up to an optimum temperature level increases mainly due to larger numbers of cercariae being produced and emerging into the environment (Studer et al. 2010). Within a second intermediate crustacean host, the parasite (metacercaria) develops into a mature cyst stage, a process which is also highly temperature dependent (Studer et al. 2010). The final transmission event occurs when a crustacean harbouring mature cysts is ingested by a definitive bird host. Within the intestine of a bird, adult worms reproduce sexually. Parasite eggs pass into the environment with the bird's faeces, where the cycle is completed with snails acquiring infections by ingesting eggs during foraging.

The overall aim of the present study was to investigate the seasonal patterns related to all transmission steps in the life cycle of Maritrema novaezealandensis on a mudflat where the prevalence in first intermediate snail hosts is known to be high, as temporal patterns in terms of host and parasite phenologies are expected to be most obvious in such a locality. Our approach comprised 3 main parts: (1) The concomitant assessment of snail and amphipod density, prevalence (\% of infected individuals) and infection intensity (for snails, as the proportion of parasite tissue within infected snails; for amphipods, as the number of metacercariae per infected individual) across all seasons; (2) An assessment of the total bird abundance on the mudflat over a $1 \mathrm{yr}$ period; (3) A year-long temperature record in tide pools to provide 
more detailed information on the thermal conditions experienced by organisms in the actual microhabitat where transmission takes place. Little seasonal variation in trematode prevalence was expected in Zeacumantus subcarinatus snails (Fredensborg et al. 2005). However, we hypothesised a strong seasonal pattern in prevalence and infection intensity in second intermediate amphipod hosts, based on the temperature sensitivity of the transmission from snails to amphipods (Studer et al. 2010). Importantly, maximum infection levels in second intermediate hosts should be synchronised such that there is an overlap with the highest availability of definitive bird hosts (e.g. Mouritsen et al. 1997). We therefore expected seasonal patterns not only with regard to host densities for snails and amphipods but also for the abundance of birds, all in accordance with an optimised potential of the parasite to complete its life cycle. Furthermore, the timing of parasite egg recruitment into the snail population may be less constrained by time, due to the persistence of eggs in the environment, but should be optimised to coincide with the presence of high numbers of uninfected, susceptible hosts at a maximum level of activity. The results presented here contribute important knowledge about the temporal dynamics of trematode parasitism in intertidal soft-sediment ecosystems.

\section{MATERIALS AND METHODS}

\section{Study organisms}

In Zeacumantus subcarinatus snails, reproduction is thought to take place from November to March (austral spring and summer) and occurs via crawlaway larvae that directly hatch from eggs, i.e. there is no or only minimal planktonic dispersal, and populations are maintained by local reproduction (Fredensborg et al. 2005). These snails have an estimated life span of at least 5 to 6 yr (Fredensborg et al. 2005) and once infected remain so for the remainder of their lives. Their size at maturity is related to the prevalence at a particular site and is $8.8 \mathrm{~mm}$ at our study site (Fredensborg \& Poulin 2006). Paracalliope novizealandiae amphipods are affected by intensity dependent mortality, with amphipods being capable of tolerating infections with few parasites but being strongly negatively affected by infections with many parasites (Fredensborg et al. 2004b, Bates et al. 2010). Due to the high abundance of $P$. novizealandiae, these amphipods are thought to be an important part of local food webs. They have an assumed life span of $\sim 9$ mo with probably 2 generations per year: an overwintering and a summer generation (Fredensborg et al. 2004b, present study). As for the definitive bird hosts, only red-billed gulls Chroicocephalus scopulinus have been confirmed as definitive hosts of Maritrema novaezealandensis to date (Fredensborg et al. 2004a, Martorelli et al. 2004). However, due to the low host specificity of most trematodes for their definitive hosts, a range of shorebirds, in particular ducks, are also highly likely to serve as definitive hosts.

\section{Study site}

Lower Portobello Bay (LPB) is an intertidal soft-sediment mudflat in the Otago Harbour $\left(45^{\circ} 50^{\prime} \mathrm{S}\right.$, $170^{\circ} 40^{\prime} \mathrm{E}_{\text {; }}$ South Island of New Zealand) that has been identified as a high prevalence area for trematode infections in Zeacumantus subcarinatus. Fredensborg et al. (2005) reported that $86.6 \%$ of the snails in this location were infected with trematodes, of which $61.5 \%$ were parasitised by Maritrema novaezealandensis. The abundance of birds has been linked to the particularly high prevalence of snail hosts on LPB (Fredensborg et al. 2006). The mudflat $(\sim 180 \times 200 \mathrm{~m}$; tidal range $\sim 2 \mathrm{~m})$ is a mosaic of shallow tide pools and exposed patches. Most of the bay is covered lightly, but some areas are densely vegetated with eelgrass Zostera novaezelandensis and/or other algae. The crustacean community in this locality has been well investigated with regard to its parasite fauna (see Koehler \& Poulin 2010). Paracalliope novizealandiae amphipods have never been found infected with any other species of parasite, and thus, $M$. novaezealandensis is the sole agent affecting the LPB population (Fredensborg et al. 2004b, Koehler \& Poulin 2010, present study). Bates et al. (2010) reported intensity-dependent mortality of amphipods from this locality based on field experiments, with amphipods at high shore locations during summer months being most at risk from high infection levels and hence having a lower likelihood of survival.

\section{Sampling of snail and amphipod hosts}

Samples were collected on 2 sampling trips per season (within a maximum of 3 wk of each other; 3 replicate samples per trip, i.e. 6 replicate tide pools per season) during low tide in haphazardly selected tide pools in the mid to upper shore area (exposure time per low tide: $\sim 4$ to $6 \mathrm{~h}$; pools $>0.5 \mathrm{~m}^{2}$ and $>3 \mathrm{~cm}$ 
deep) using a $0.5 \mathrm{~m}^{2}$ rectangular aluminium box. Sampling was done haphazardly because the nature of the system required the selection of tide pools of appropriate size and depth upon arrival. The sampling was done in the mid-upper shore area for the following reasons: (1) lower shore areas often have no defined tide pools, (2) the use of this area ensured enough time to complete the sampling and (3) amphipods at mid- and upper shore heights are most influenced by the parasite (Bates et al. 2010), and hence, transmission dynamics should be most pronounced in this area of the mudflat. Amphipods were sampled within the enclosed area using a dip-net with a $250 \mu \mathrm{m}$ mesh size. Subsequently, snails were collected from within the enclosure by finger dredging. Both amphipods and snails were sampled as thoroughly as possible and stored in separate 31 plastic containers for transport back to the laboratory. For all of the statistical analyses described in detail below, replicates from the 2 sampling trips were pooled to increase the sample size per season for a better indication of the variability within seasons compared to the variability among seasons.

\section{First intermediate snail hosts}

For density estimates, live snails from each sample were counted, and the shell lengths were measured using callipers. For the assessment of prevalence, snails were screened by incubation. This method is a non-destructive and conservative approach that only identifies mature infections and therefore underestimates true prevalence. To increase the accuracy of the method, snails collected in the field were first stored at relatively constant conditions in the laboratory for $1 \mathrm{wk}$, allowing time for the maturation of cercariae. Furthermore, snails from which no cercariae emerged during the first incubation were screened again after another week of storage in the laboratory to allow for a second round of maturation. For the incubations, snails were placed individually in wells $(20 \times 23 \mathrm{~mm})$ of a 12 -well plate containing $3 \mathrm{ml}$ of seawater and exposed under constant illumination at $25^{\circ} \mathrm{C}$ for several hours. Cercariae were identified according to species descriptions of local parasites (Martorelli et al. 2004, 2006, 2008). Due to the high morphological similarity between the cercariae of Maritrema novaezealandensis and Microphallus sp. (prevalence of Microphallus sp. <2\%; Martorelli et al. 2008), the 2 species were not distinguished, and the proportion of each was later calculated based on an estimated $1 \%$ of 'Maritrema' -infected snails being infected with Microphallus sp. ( $\mathrm{n}=100)$. After the screenings, the snails were returned to the mudflat. Arbitrarily, only snails $\geq 8 \mathrm{~mm}$ were considered in the analyses (see below) because the reliability of sampling smaller snails with the method of finger-dredging employed is limited.

As a measure of infection intensity, a minimum of 30 snails of similar size infected with Maritrema novaezealandensis (mean shell length \pm standard error, $14.28 \pm 0.12 \mathrm{~mm}$ ) was used each season to assess the proportion of the overall wet weight of the snails actually consisting of parasite tissue (sporocysts). For this, snails were dried on a paper towel for $15 \mathrm{~min}$, and snail shell length was measured before weighing the snails (all weights recorded to the nearest $0.0001 \mathrm{~g}$ ). The snails were cracked open and dissected in a drop of seawater. The parasite tissue was isolated, and the excess liquid was absorbed using a paper towel before weighing. For a subset of snails $(n=32)$, the soft tissue of the snail was also weighed to calculate the proportion of infected tissue from the total snail weight including and excluding shell weight.

For the statistical analysis, differences in the density of snails between seasons were analysed using a generalised linear model (GLM) fitted with a quasiPoisson error structure. A GLM fitted with a binomial error structure was used to assess the effects of the season and size of snails on the infection status of snails. The effect of season on the proportion of parasite tissue from the total snail weight was analysed using a GLM fitted with a quasi-binomial error structure.

\section{Second intermediate amphipod hosts}

For density estimates, amphipods were either counted or their numbers estimated (counts in subsamples) in samples with many small individuals. When too few amphipods $\geq 2.25 \mathrm{~mm}$ (minimum size limit for sex determination) were collected during the sampling, additional amphipods were obtained by random sampling in various tide pools to ensure that an adequate number of amphipods was dissected per season. The amphipods were measured (body length; size classes: $2.5,3.0,3.5,4.0, \geq 4.5 \pm 0.25 \mathrm{~mm}$ ) and sexed prior to dissection. Upon dissection, the number and developmental stages of the metacercariae of Maritrema novaezealandensis within the amphipods were assessed. The developmental stages distinguished were early immature, late immature, early cyst and mature cyst stage (according to Keeney et al. 2007). 
Differences in amphipod density between seasons were analysed using a GLM fitted with a quasi-Poisson error structure. Using the entire dataset for all amphipods $\geq 2.25 \mathrm{~mm}$, the effects of the season and the sex and size of amphipods on their infection status were analysed using a GLM fitted with a binomial error structure. For all infected amphipods $\geq 2.25 \mathrm{~mm}$, the effects of season, sex and size of amphipods on the number of infecting parasites (i.e. infection intensity) was analysed with a GLM fitted with a quasiPoisson error structure.

\section{Definitive bird hosts}

The mudflat was visited 12 to 14 times per season during low tide, and all birds present on the entire mudflat, including birds wading along the waterline, were counted (1 count per visit upon arrival based on spotting by eye and with binoculars). To date, only red-billed gulls have been confirmed as final hosts of Maritrema novaezealandensis (Fredensborg et al. 2004a). However, trematodes often show little specificity in definitive hosts, and therefore, the total number of birds present was counted regardless of species. The mean bird abundance per season was calculated, and the months when the most birds were present were identified.

\section{In situ temperature logging}

To describe the thermal conditions in tide pools in which essentially all of the transmission steps of Maritrema novaezealandensis take place, 5 temperature loggers (DS 1921 Thermochron iButtons; $\pm 0.5^{\circ} \mathrm{C}$ ) were installed in haphazardly selected pools in the mid to upper shore area of the mudflat (the pools varied in size and degree of vegetation). The loggers, wrapped in a strip of Parafilm, were placed in white submersible housings (HOBO SUBC2-WH, $10 \times$ $6.5 \mathrm{~cm}$ ), which were attached with cable ties to a 60 $\mathrm{cm}$ stainless steel pole anchored in the sediment. The main bodies of the housings were constantly submerged in water. The temperature was recorded in 30 min intervals. Logger data was downloaded monthly during the logging period (November 2009 to November 2010). Average data from 4 loggers are presented; readings from the fifth logger were omitted because its pool was covered with a thick layer of sludge for extended periods. To compare logger derived temperature data with actual conditions in the tide pools directly, additional measurements were taken on several occasions with a digital thermometer. To compare the temperature data from the mudflat with the temperature from the main water body of the harbour, daily temperatures measured at the nearby Portobello Marine Laboratory were obtained.

The temperature data from the loggers was then used to calculate the time that the average temperature in tide pools exceeded 15 and $20^{\circ} \mathrm{C}$, respectively, in each season. As a measure of transmission pressure, seasonal differences in total cercarial densities emerging from infected snails into the environment per $0.5 \mathrm{~m}^{2}$ were calculated. This estimation was based on the average snail density and snail prevalence found in the present study (see 'Results') and known emergence rates of cercariae at these temperatures (average number of cercariae emerging per infected snail per hour being 1.2 at 15 to $16^{\circ} \mathrm{C}$ and 32.2 at $\geq 20^{\circ} \mathrm{C}$; Studer et al. 2010).

\section{RESULTS}

\section{First intermediate snail hosts}

\section{Density}

Snail density did not differ among seasons at the $5 \%$ significance level (GLM, quasi-Poisson; $F_{3,20}=$ 2.94, $\mathrm{p}=0.058$ ). Nonetheless, the mean density was higher in summer and fall than in winter and spring (Table 1, Fig. 1), with an overall mean density of 161.3 snails (range: 1 to 1053 ) $0.5 \mathrm{~m}^{-2}$. The mean shell length $( \pm 1 \mathrm{SE})$ of snails $(\geq 8 \mathrm{~mm})$ was $13.67 \pm 0.04 \mathrm{~mm}$ ( $\mathrm{n}=3043$ ) (winter: $14.02 \pm 0.11 \mathrm{~mm}, \mathrm{n}=257$; spring: $14.47 \pm 0.11 \mathrm{~mm}, \mathrm{n}=356$; summer: $14.11 \pm 0.06 \mathrm{~mm}$, $\mathrm{n}=1197$; fall: $12.95 \pm 0.08 \mathrm{~mm}, \mathrm{n}=1233$ ).

\section{Prevalence}

The overall trematode prevalence in snails was $64.5 \%$ ( $\mathrm{n}=3423$ ) for snails $\geq 8 \mathrm{~mm}$. Of these infections $88.4 \%$ consisted of Maritrema novaezealandensis. Besides infections with $M$. novaezealandensis, infections with the following trematodes were found: Philophthalmus sp. (prevalence: $4.7 \%$ ), Acanthoparyphium sp. (3.0\%), Galactosomum sp. (0.8\%), Microphallus sp. $(0.1 \%)$ and double infections of $M$. novaezealandensis and Philophthalmus sp. (1.3\%) or $M$. novaezealandensis and Galactosomum sp. (0.1\%). The highest prevalences of $M$. novaezealandensis in snails were found in winter (71.6\%) and spring 
Table 1. Maritrema novaezealandensis and its hosts. Prevalence and infection intensity of snails Zeacumantus subcarinatus and amphipods Paracalliope novizealandiae from the Lower Portobello Bay mudflat across all 4 seasons. Prevalence (percentage of hosts infected; for snails: overall trematode prevalence and prevalence of $M$. novaezealandensis in brackets) and infection intensity (snails: percentage of snail weight due to parasite biomass; amphipods: number of metacercariae per host; all $\pm 1 \mathrm{SE}$ ) are reported. Results are based on organisms from 6 replicate samples per season (pooled from 2 sampling trips)

\begin{tabular}{|c|c|c|c|c|}
\hline & Snails & $\mathrm{n}$ & Amphipods & $\mathrm{n}$ \\
\hline \multicolumn{5}{|c|}{ Prevalence } \\
\hline Winter & $71.6 \pm 0.03(61.1)$ & 257 & $3.3 \pm 0.01$ & 540 \\
\hline Spring & $78.1 \pm 0.02(63.8)$ & 356 & $60.6 \pm 0.03$ & 274 \\
\hline Summer & $64.4 \pm 0.01(59.3)$ & 1577 & $90.6 \pm 0.02$ & 320 \\
\hline Fall & $59.2 \pm 0.01(51.2)$ & 1233 & $68.4 \pm 0.02$ & 389 \\
\hline \multicolumn{5}{|c|}{ Infection intensity } \\
\hline Winter & $8.1 \pm 0.5$ & 32 & $1.1 \pm 0.1$ & 18 \\
\hline Spring & $8.6 \pm 0.4$ & 30 & $6.7 \pm 1.4$ & 178 \\
\hline Summer & $9.1 \pm 0.5$ & 31 & $11.4 \pm 1.0$ & 339 \\
\hline Fall & $8.1 \pm 0.4$ & 32 & $5.2 \pm 0.5$ & 287 \\
\hline
\end{tabular}

$(78.1 \%)$ (Table 1), and the infection status of snails was significantly influenced by the season and size of snails (GLM, binomial; season: $\chi^{2}=10.02, \mathrm{df}=3, \mathrm{p}=$ 0.018 ; size: $\chi^{2}=289.12, \mathrm{df}=1, \mathrm{p}<0.001$ ). In fall, the high number of small snails collected led to the lowest prevalence observed (Table 1, Fig. 2). Infected snails (of all snails $\geq 8 \mathrm{~mm}$ ) were generally larger than uninfected snails, with an average of $14.21 \pm 0.05 \mathrm{~mm} \mathrm{(max}$. $\left.24 \mathrm{~mm}_{i} \mathrm{n}=2028\right)$ and $12.59 \pm 0.08 \mathrm{~mm}$ (max. $\left.21 \mathrm{~mm}_{i} \mathrm{n}=1015\right)$ for infected and uninfected snails, respectively. The proportion of infected snails was lowest for small snails, increased for snails 11 to $16 \mathrm{~mm}$ and then roughly levelled off (the proportion was $100 \%$ for the largest snails, but note the very small sample sizes; Fig. 3). The double shedding approach used to assess infection status indicated that $\sim 25 \%$ of those snails originally assessed as uninfected were subsequently identified as infected. An additional accuracy assessment also showed that $10 \%$ of snails identified as uninfected after 2 rounds of incubation were indeed infected (50 uninfected snails dissected; 2 infected by Philophthalmus sp. and 3 by $M$. novaezealandensis).

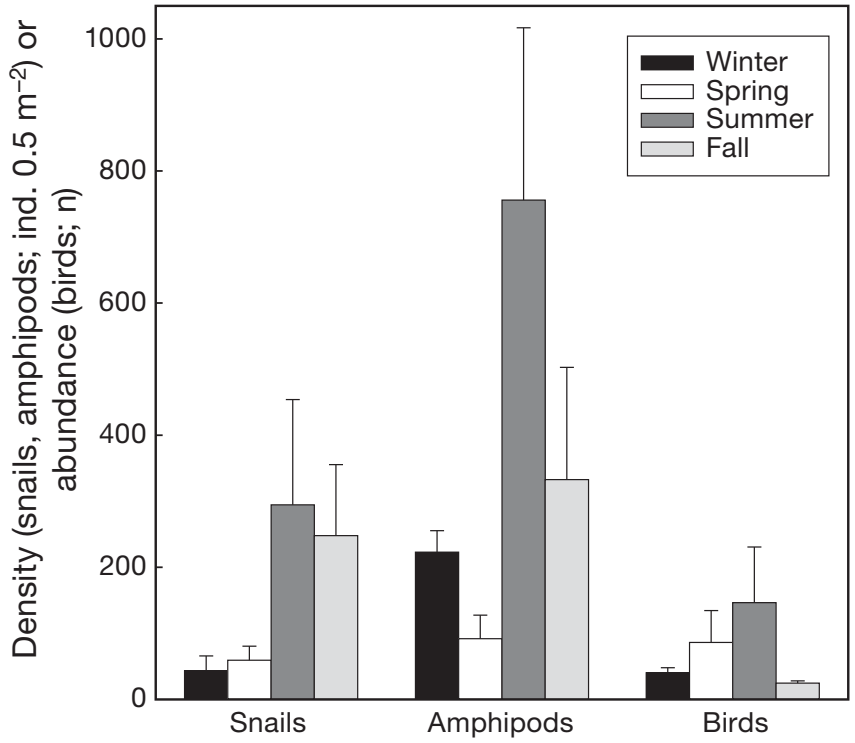

Fig. 1. Hosts of Maritrema novaezealandensis. Density of Zeacumantus subcarinatus snails and Paracalliope novizealandiae amphipods (per $0.5 \mathrm{~m}^{2}$ ) and abundance of birds on the Lower Portobello Bay mudflat across 4 seasons $($ mean $\pm 1 \mathrm{SE})$

\section{Infection intensity}

On average, $8.5 \pm 0.22 \%(\mathrm{n}=125)$ of the total Zeacumantus subcarinatus snail weight (including shell) and $36.8 \pm 0.98 \%$ of the soft tissue weight (excluding shell) was Maritrema novaezealandensis tissue. The
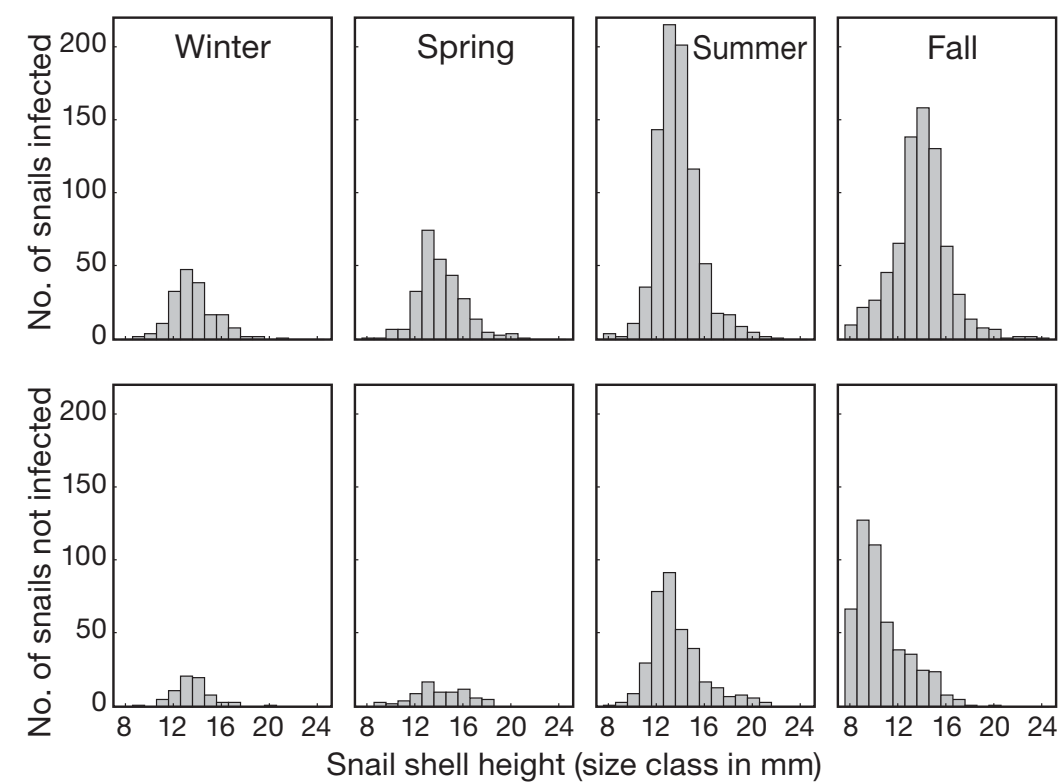

Fig. 2. Zeacumantus subcarinatus. Size frequency distributions (shell height in $\mathrm{mm}$, grouped into size classes) of all snails infected with Maritrema novaezealandensis and all uninfected snails collected across 4 seasons 


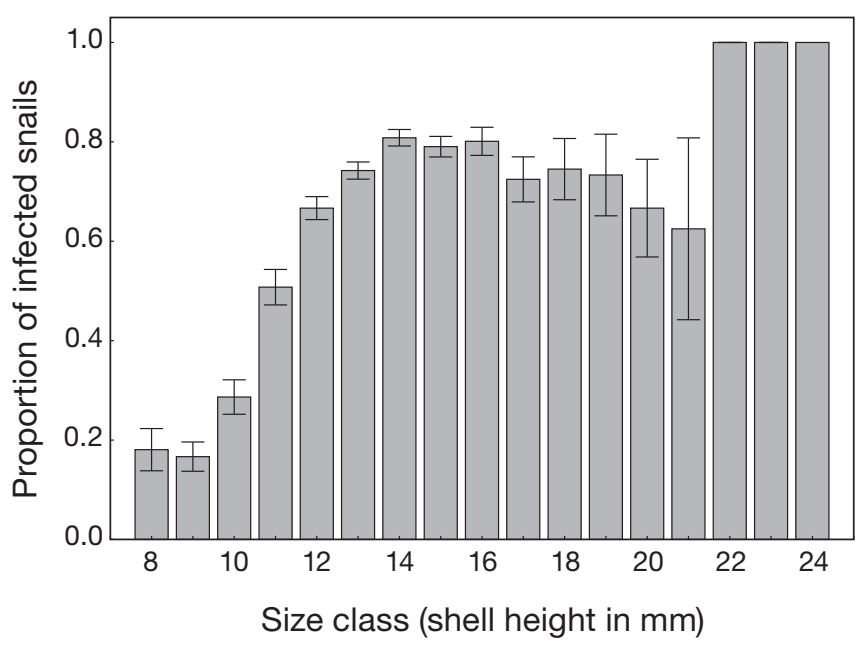

Fig. 3. Zeacumantus subcarinatus. Proportion of snail hosts $( \pm 1 \mathrm{SE})$ infected with Maritrema novaezealandensis per size class pooled across all seasons (shell height in $\mathrm{mm}$ ) (for each size class from 8 to $24 \mathrm{~mm}: \mathrm{n}=83,162,171,197,414,644$, $563,391,201,98,51,30,24,8,3,2$, and 1 ; note small sample size for largest size classes)

mean weight of the parasite tissue in a snail was $0.017 \pm 0.001 \mathrm{~g}$. The proportion of parasite tissue in snail hosts did not differ significantly between seasons (GLM, quasi-binomiali $F_{3,121}=1.16, \mathrm{p}=0.329$ ) (Table 1).

\section{Second intermediate amphipod hosts}

\section{Density}

Amphipod density varied significantly between seasons (GLM, quasi-Poisson; $F_{3,20}=4.62, \mathrm{p}=0.013$ ) and was by far the highest in summer and lowest during spring (Fig. 1). Overall, the average amphipod density was 350.0 (range 4 to 1926) $0.5 \mathrm{~m}^{-2}$. For amphipods $\geq 2.25 \mathrm{~mm}$, the size class distributions were relatively similar across seasons, except that amphipods $\geq 4.25 \mathrm{~mm}$ (i.e. males; adult males are larger than females, with maximum body lengths for females of $3.5 \mathrm{~mm}$ and $5.0 \mathrm{~mm}$ for males) were absent, and only few were present from the second largest size class $(4.0 \pm 0.25 \mathrm{~mm})$ in summer (Fig. 4). Juvenile amphipods $(<2.25 \mathrm{~mm})$ were mostly collected in summer and fall. There was a positive correlation between amphipod and snail density within the sampled areas (Spearman's $\rho=0.46, p=0.002$ ), indicating that in enclosures where many snails were counted, comparatively many amphipods were also present.

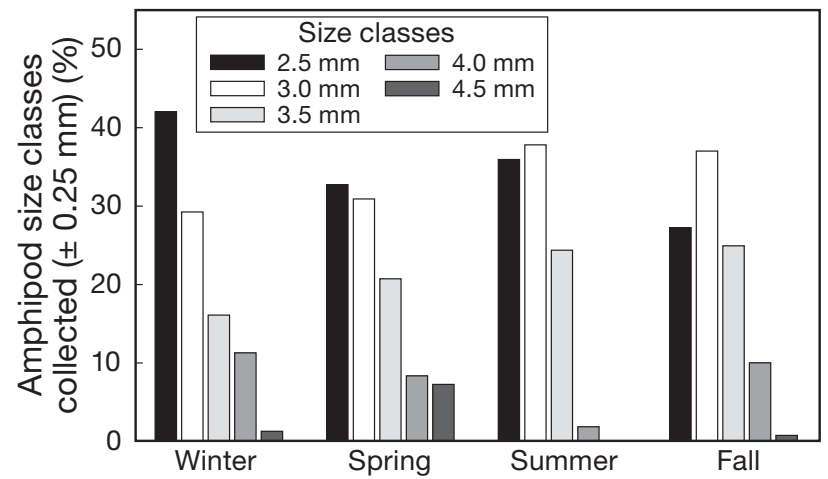

Fig. 4. Paracalliope novizealandiae. Percentage of size classes of amphipods (body length 2.5, 3.0, 3.5, 4.0 and $\geq 4.5 \pm$ $0.25 \mathrm{~mm}$ ) collected across seasons

Prevalence

The proportion of infected amphipods showed a strong seasonal pattern, with the highest prevalence $(>90 \%)$ in summer (Table 1). Season and the sex and size of amphipods all had a significant effect on amphipod infection status (GLM, binomial; season: $\chi^{2}=925.92, \mathrm{df}=3$; sex: $\chi^{2}=15.04, \mathrm{df}=1$; size: $\chi^{2}=$ 131.11, $\mathrm{df}=4 ; \mathrm{p}<0.001$ for all; Fig. 5), with larger amphipods and males having a higher prevalence. Within the same size class (comparing 2.5, 3.0 and 3.5 $\pm 0.25 \mathrm{~mm}$ separately), the proportion of infected amphipods did not differ between sexes (MannWhitney $U, \mathrm{p}>0.05$ for all comparisons).

\section{Infection intensity}

There was also a seasonal pattern with regard to the number of metacercariae per infected amphipod. Mean infection intensity was lowest in winter (range

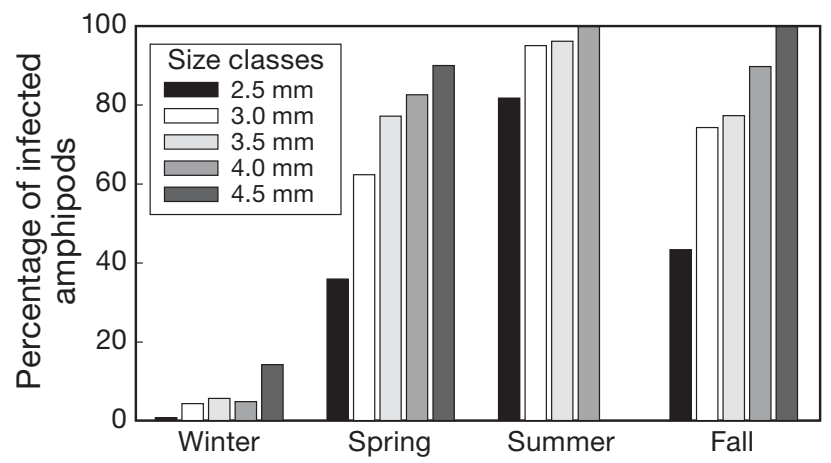

Fig. 5. Paracalliope novizealandiae. Percentage of amphipods infected with Maritrema novaezealandensis per size class (body length $2.5,3.0,3.5,4.0$ and $\geq 4.5 \pm 0.25 \mathrm{~mm}$ ) across all seasons. Note: largest size class missing in summer 
1 to 19) and highest in summer (range 1 to 202) (Table 1). The effects of season and the sex and size of amphipods on the number of parasites per amphipod were significant (GLM, quasi-Poisson; season: $F_{3,733}=$ 24.27; sex: $F_{1,733}=43.53$; size: $F_{4,733}=30.81 ; \mathrm{p}<0.001$ for all). Males were on average more infected than females, and larger amphipods were more infected than smaller ones. The mean infection intensities varied from $6.1 \pm 0.4$ (females) to $11.3 \pm 1.1$ (males) and from $4.6 \pm 0.5$ ( $2.5 \pm 0.25 \mathrm{~mm}$ size class $)$ to $30.1 \pm 10.1$ metacercariae per amphipod $(\geq 4.5 \pm 0.25 \mathrm{~mm}$ size class). When comparing infection intensities in the same size class separately, there was a significant effect of sex, with males being more infected than females in the 3.0 and $3.5 \mathrm{~mm}$ size classes (Mann Whitney $U, 3.0 \mathrm{~mm}: Z=-3.39, \mathrm{p}<0.001 ; 3.5 \mathrm{~mm}: Z=$ $-2.64, \mathrm{p}=0.01$ ) but not in the $2.5 \mathrm{~mm}$ size class. Developmental stages of the metacercariae also showed seasonal patterns (Fig. 6). Early immature metacercariae, indicating recent infection events, were mostly present in spring, summer and fall. As an indication of advanced development and hence the presence of infective metacercariae, early and mature cysts were most prevalent in summer and fall.
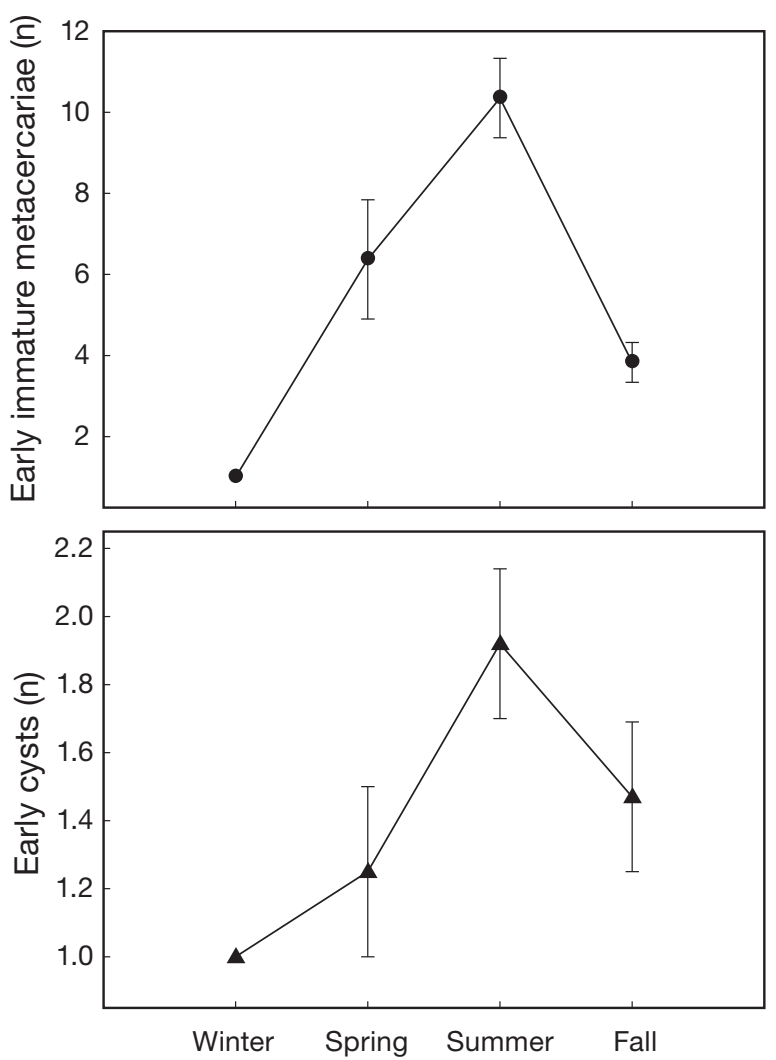

\section{Definitive bird hosts}

A seasonal pattern was also observed for the abundance of birds, with highest numbers visiting the mudflat from October to January (austral spring and summer) (Fig. 1). The most common species observed were red-billed gulls Chroicocephalus scopulinus, black-backed gulls Larus dominicanus, oystercatchers (pied Haematopus ostralegus finschi and variable $H$. unicolor) and ducks (especially paradise shell ducks Tadorna variegata and mallards Anas platyrhynchos platyrhynchos). The large flocks visiting the mudflat during summer were mostly gulls (red-billed and black-backed), whereas the most consistent birds present on the mudflat throughout the year were ducks.

\section{Temperature}

The mean temperature measured by the loggers was $11.7^{\circ} \mathrm{C}$. The highest temperatures were recorded from the end of November 2009 to March 2010, whereas the coldest period was between June and
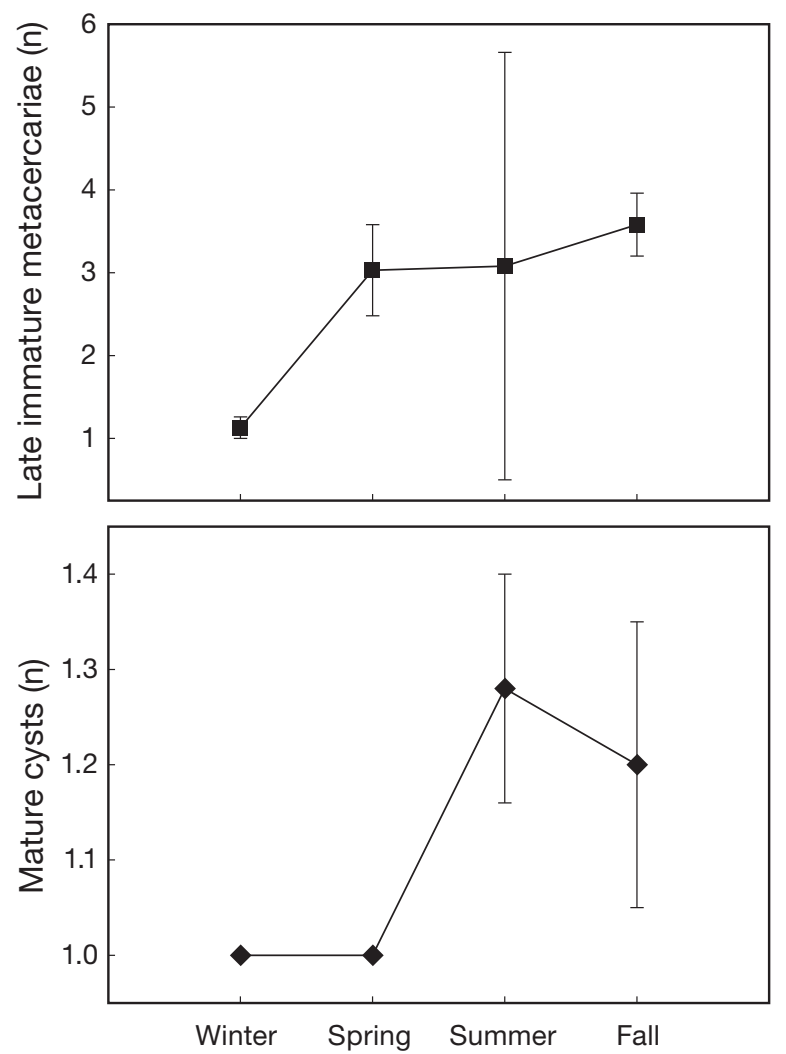

Fig. 6. Maritrema novaezealandensis. Mean $( \pm 1 \mathrm{SE})$ number of metacercariae at different developmental stages, i.e. early immature ( $)$, late immature $(\boldsymbol{\square})$, early cyst $(\boldsymbol{\Delta})$ and mature cyst stage $(\bullet)$, in infected Paracalliope novizealandiae amphipods by season (see Keeney et al. 2007 for illustrations of the different stages) 
July 2010 (max.: $26.5^{\circ} \mathrm{C}_{\text {; } \min .:} 3.0^{\circ} \mathrm{C}$ ) (Fig. 7). The magnitude of daily fluctuation of temperature was greatest in summer $\left(>10^{\circ} \mathrm{C}\right.$ compared to $0.5^{\circ} \mathrm{C}$ in winter). Data measured daily from the main water body of the harbour at the nearby Portobello Marine Laboratory for the same period showed a mean temperature of $11.6^{\circ} \mathrm{C}$, minimum of $6.5^{\circ} \mathrm{C}$ and maximum of $18.1^{\circ} \mathrm{C}$. During warmer months, the temperatures measured on the mudflat were generally higher than those measured from the main water body in the harbour, whereas during the colder months, they were lower (Fig. 7). Additional temperature measurements taken with a digital thermometer indicated that especially during warm periods, loggers underestimated the actual water temperature on average by $\sim 2.4^{\circ} \mathrm{C}$. With a digital thermometer, temperatures $>30^{\circ} \mathrm{C}$ were measured in several tide pools on one occasion (2 February 2010).

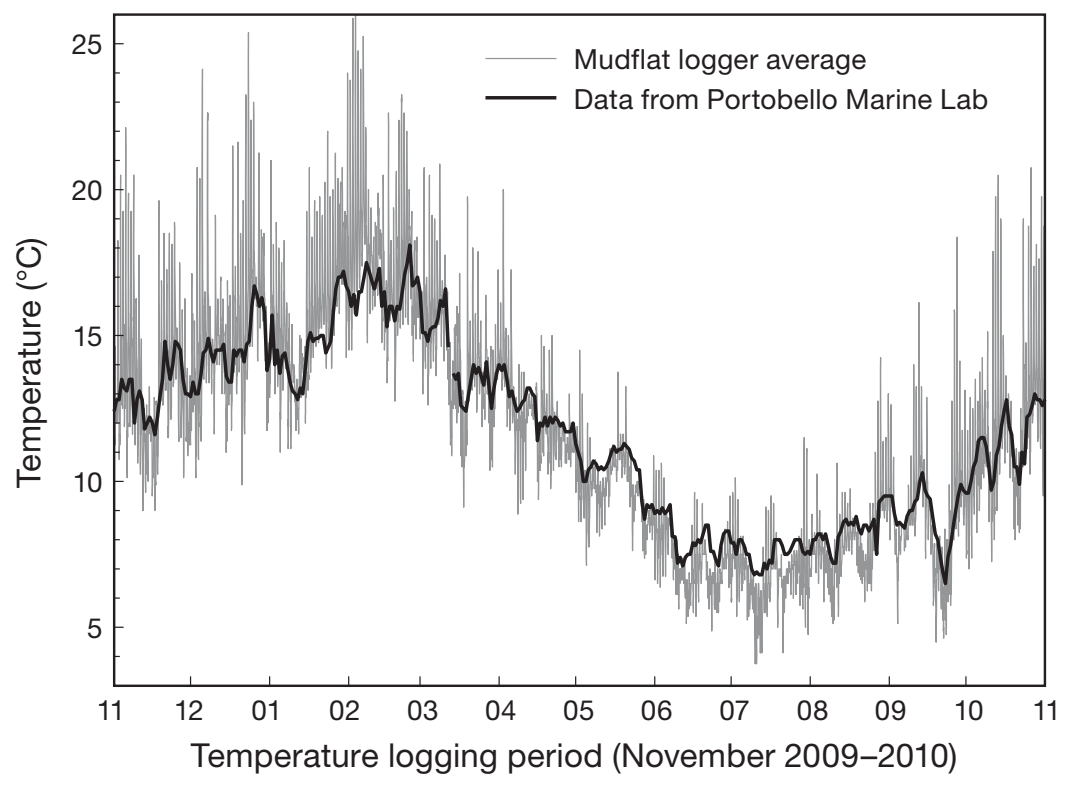

Fig. 7. Average temperature profile from 4 loggers deployed in tide pools on the Lower Portobello Bay mudflat from November 2009 to 2010 (grey line) and additional daily measurements obtained at the nearby Portobello Marine Lab from the main water body of the harbour during the same period (black line)

\section{Transmission pressure}

The number of hours $\geq 15$ and $\geq 20^{\circ} \mathrm{C}$ showed a strong seasonal pattern, with maxima in summer (Table 2). During winter, temperatures did not exceed $15^{\circ} \mathrm{C}$. As a consequence, the estimated density of cercariae per $0.5 \mathrm{~m}^{2}$ also showed a strong seasonal pattern, with maximum transmission pressure on second intermediate hosts during summer. The density of metacercariae in amphipods based on the results from the present study (calculated as the density of infected amphipods $\times$ infection intensity) followed the same seasonal pattern (Table 2).

\section{DISCUSSION}

Seasonal fluctuations in the hosts

Table 2. Maritrema novaezealandensis. Seasonal differences in cercariae and metacercariae density on the Lower Portobello Bay mudflat. Estimation of cercarial density was based on the number of hours that temperature in tide pools exceeded $15^{\circ} \mathrm{C}$ and $20^{\circ} \mathrm{C}$ per season according to the logger data (Fig. 7), an average snail density of 161 per $0.5 \mathrm{~m}^{2}$, prevalence as stated in the results and an emergence rate of 1.2 and 32.2 cercariae $\mathrm{h}^{-1}$ at 15 and $\geq 20^{\circ} \mathrm{C}$, respectively (Studer et al. 2010). The density of metacercariae in infected amphipods per $0.5 \mathrm{~m}^{2}$ and season is based on amphipod density, prevalence and infection intensity as stated in the results of the present study

\begin{tabular}{|lcccc|}
\hline Season & \multicolumn{2}{c|}{$\begin{array}{c}\text { Emergence } \\
\text { duration }(\mathrm{h}) \\
\geq 15^{\circ} \mathrm{C}\end{array} \geq 20^{\circ} \mathrm{C}$} & $\begin{array}{c}\text { Cercariae } \\
(\text { no. ind. } \\
\left.0.5 \mathrm{~m}^{-2}\right)\end{array}$ & $\begin{array}{c}\text { Metacercariae } \\
(\text { no. ind. } \\
\left.0.5 \mathrm{~m}^{-2}\right)\end{array}$ \\
\hline Winter & 0 & 0 & 0 & 8 \\
Spring & 197 & 7 & 47584 & 373 \\
Summer & 1264 & 128 & 535592 & 7808 \\
Fall & 249 & 4.5 & 36432 & 1183 \\
\hline
\end{tabular}

involved in all stages of the complex life cycle of the intertidal trematode parasite Maritrema novaezealandensis were investigated to reveal patterns of host availability and population dynamics (density of snails and amphipods, abundance of birds), parasite population parameters (prevalence and intensity of infections in snails and amphipods) and thermal microhabitat conditions on a mudflat where infection levels are high. Although some aspects of the study remain largely descriptive and correlative at this point and despite the fact that the temporal resolution was only relatively low and the study was only conducted during one year, the findings presented here add important knowledge to our current understanding of trematode ecology in intertidal ecosystems and moreover allow a range of inferences to be made about the study system that may be relevant for comparable systems in other locations. 
Seasonal differences were found in the amphipod host density, total bird abundance, prevalence in snails and amphipods and infection intensity in amphipods. Except for snail prevalence, which peaked in winter/spring, all of the parameters peaked in summer. In addition, the strong seasonal fluctuations of temperature in tide pools allowed estimations of the durations of cercarial emergence from infected snail hosts and thus seasonal differences of theoretical cercarial densities and hence transmission pressure on second intermediate crustacean hosts. In contrast to these pronounced seasonal patterns, no statistically significant effects of season could be found on snail density and infection intensity. Thus, as density- and parasite-related parameters in snail first intermediate hosts remained relatively stable, temperature-mediated parasite transmission from first to second intermediate hosts seems to be the likeliest main cause of the strong seasonal pattern observed for infection levels in amphipod hosts. The peaks in density, prevalence and infection intensity in amphipods and hence the highest density of metacercariae during warmer months further coincided with the highest abundance of bird hosts visiting the study location. Moreover, this also coincided with the highest number of small and still uninfected snails present in the system, allowing parasite recruitment into a new snail cohort. These results indicate that the entire life cycle of this parasite and all transmission steps are substantially accelerated during warmer compared to colder months.

\section{First intermediate snail hosts}

The density of Zeacumantus subcarinatus snails was not significantly different among seasons due to substantial variability among the samples. Nonetheless, the mean densities tended to be higher in summer and fall (Table 1, see also Fig. 2). The discrepancy between this observation and the statistical result was probably due, at least to some degree, to the size-selectivity of the sampling method and seasonal changes in snail activity on the mudflat affecting the probability of collection. Detection of seasonal population dynamics should be possible even in a location like LPB through the adaptive mechanism of early maturation, ensuring reproduction in snail populations where the prevalence of castrating trematodes is high (Fredensborg \& Poulin 2006).

Our study confirmed that LPB is indeed a high prevalence location for Maritrema novaezealand- ensis in first intermediate Zeacumantus subcarinatus snail hosts. Despite the expectation of a relatively stable prevalence across seasons in this relatively long-lived species (Fredensborg \& Poulin 2006), the higher number of especially small and still uninfected snails collected in summer and fall lead to the prevalence in snails being significantly lower than in other seasons. This, however, should not affect the increased transmission pressure from infected snail hosts during warmer seasons because the density of infected snails was highest in summer and fall despite the lower prevalence (see 'Results' and below). Other studies have reported different seasonal patterns, with lows in prevalence during winter and spring and peaks in summer (e.g. Hughes \& Answer 1982, Mouritsen et al. 1997, Kube et al. 2002b and references therein) or similar patterns of maximum levels in winter and spring (e.g. Al-Kandari et al. 2000). Seasonal changes in trematode prevalence in snail hosts have been attributed to the life history of the snail host, e.g. age structure, recruitment or mortality, seasonal changes in ambient temperatures or the biology of the final hosts, including abundance or behaviour (Kube et al. 2002b and references therein). Also, seasonal infection patterns in snail hosts have been linked to infection-status-specific winter migration toward low shore and subtidal areas (Sindermann 1960, Sindermann \& Farrin 1962), a possibility that remains unexplored in the system studied here but that may account for some of the patterns observed.

Prevalence in our study was determined using a non-destructive method of sequential shedding coupled with allowing cercariae time to mature. Shedding of cercariae might considerably underestimate the true prevalence in a snail population (Curtis \& Hubbard 1990). The approach chosen in our study aimed to be non-destructive while allowing a large number of snails to be assessed. The precautions taken to increase the accuracy of the method substantially increased the detection of infected snails. However, our results confirmed that even sequential shedding of cercariae from infected snails still leads to an underestimation of the true prevalence. Also, the approach did not allow detection of the potential seasonal changes in infection incidence, i.e. parasite recruitment into the snail population based on levels of immature infections in snails.

The proportions of infected snails per size class (i.e. shell height) indicated a sharp increase for small sizes $\geq 8 \mathrm{~mm}$. For size classes $\geq 12 \mathrm{~mm}$, the proportion of infected snails remained relatively high 
(Fig. 3), not providing strong evidence for parasiteinduced mortality among larger size classes. Increasing prevalence with shell height of snail hosts has also been shown in other studies (e.g. Hughes \& Answer 1982, Al-Kandari et al. 2000, Kube et al. 2002a; but see e.g. Fredensborg et al. 2005, Al-Kandari et al. 2007) and is due to the fact that with increasing size and age of a snail, there is a higher probability of having become infected due to the longer period of exposure to parasite eggs. In addition, no indication of seasonal differences or size-dependent snail mortality was found based on the collection of empty but intact snail shells (A. Studer unpubl. data). Based on the different mortality of infected and uninfected snails in a range of snail-trematode system, in particular under exposure to physiological stress (e.g. McDaniel 1969, Tallmark \& Norrgren 1976, Lafferty 1993; but see Sousa \& Gleason 1989), and as shown for the snailtrematode system studied here (Fredensborg et al. 2005), an increased mortality in summer and fall may have been expected as a result of the increased physical damage caused by cercarial shedding at higher temperatures. The lack of evidence may be due to the fact that this difference in mortality is mitigated or offset by sufficient food availability in natural systems during warmer seasons (Fredensborg et al. 2005).

There was no significant seasonal pattern in trematode biomass in snails. This is in contrast to the seasonal difference described by Hechinger et al. (2009) for trematode biomass in Cerithidea californica snails. Parasite biomass in natural systems has only recently been recognised as substantial, in particular in the case of trophically transmitted parasites and parasitic castrators (Kuris et al. 2008, Hechinger et al. 2009). The trematode biomass for the area of the LPB mudflat from Zeacumantus subcarinatus snails alone was estimated to be $\sim 35.3 \mathrm{~kg} \mathrm{ha}^{-1}$. This is comparable to the results for trematodes in Kuris et al. (2008) but clearly exceeds the 1 to $10 \mathrm{~kg} \mathrm{ha}^{-1}$ specified for parasitic castrators and trophically transmitted parasite stages. Moreover, the percentage of soft-tissue weight of individual infected snails in the case of Maritrema novaezealandensis in $Z$. subcarinatus $(36.8 \%)$ matches the upper range of what has been described for various trematode species infecting $C$. californica (6 to $49 \%$ ) and is well above the 20 to $28 \%$ described in earlier studies of other castrating trematodes (Hechinger et al. 2009 and references therein). However, differences in the methodologies used in these studies limit a rigourous comparison.

\section{Second intermediate amphipod hosts}

The amphipod host population of LPB showed strong and consistent seasonal patterns of density, prevalence and infection intensity. The density of amphipods was highest in summer and fall mainly due to the high number of juveniles. The proportion of gravid females showed a peak in summer, while the mean number of eggs per ovigerous female was highest in spring, marking the time of maximum reproductive output in the LPB amphipod population (A. Studer unpubl. data). The density of amphipods was lowest in spring, which in other systems has been attributed to mortality of the overwintering generation after reproduction in spring and/or mortality and drifting of juveniles (e.g. Meißner \& Bick 1997). Infection-mediated subtidal migration during colder months and cold tolerance remain unexplored in this species of amphipod. Nonetheless, densities were considerably higher in winter than in spring, not providing strong evidence for either potential mechanism. In other studies, similar peaks in amphipod density were found in summer (e.g. Meißner \& Bick 1997, Mouritsen et al. 1997). Patterns of amphipod or other crustacean second intermediate host populations usually reflect annual cycles of reproduction and recruitment (e.g. Jensen et al. 2004) but can be affected substantially by bird predation (Mouritsen et al. 1997) and may also show strong site and interannual variation (e.g. Jensen et al. 2004).

The seasonal pattern of density was accompanied by seasonal patterns of prevalence and infection intensities. Compared to winter, the substantially higher prevalence and infection intensity in spring indicated that even a few transmission events (based on temperature spikes in Fig. 7 and on the time exceeding 15 and $20^{\circ} \mathrm{C}$ in Table 2) can rapidly increase infection levels in amphipod hosts. In summer, all of the amphipod size classes were similarly affected in terms of prevalence (Fig. 5). The surprisingly high infection intensities in amphipods (well above 100 parasites per amphipod of the same early developmental stage) confirmed that 'bursts' of cercarial emergence occur (Fredensborg et al. 2004b, Keeney et al. 2007). Some of these heavily-infected amphipods were captured because sampling took place during optimal conditions for transmission, which presumably occurs during low tides when water temperatures in tide pools increase, exceeding the minimum temperature for cercarial production and emergence from snails (Mouritsen \& Jensen 1997, Fingerut et al. 2003, Fredensborg et al. 2005, Al-Kan- 
dari et al. 2007, Studer et al. 2010). Amphipods infected with a certain number of metacercariae beyond a lethal threshold are, however, unlikely to survive for long (Fredensborg et al. 2004b, Bates et al. 2010). Similar peaks of infection in second intermediate crustacean hosts have been reported for summer periods in other host-parasite systems (Mouritsen et al. 1997, Latham \& Poulin 2003, Al-Kandari et al. 2007, Smith 2007). The study of Jensen et al. (2004), however, illustrates that peaks of infection in second intermediate hosts may also be reached in winter which has been linked to the fact that their study site is an important overwintering ground for a range of migrating birds that serve as definitive hosts.

\section{Definitive bird hosts}

Although our assessment remains only descriptive at this stage, the large bird flocks and hence the peak in abundance of birds in the present study was consistent with the main breeding season of gulls in the area (see also McClatchie et al. 1991). During summer, the presence of large numbers of birds coincided with the highest density and infection levels in amphipods and hence the highest density of metacercariae, including mature cysts. This is in accordance with the expectation that to maximise transmission, the highest infection levels in second intermediate hosts should be synchronised with the highest number of definitive hosts available. Nonetheless, parasite transmission from amphipods to birds, such as ducks, may be possible all year round because these birds were present throughout the year, and mature cysts in amphipods were also found throughout the year, albeit in low numbers. Also, in longer-lived second intermediate crustacean hosts, such as crabs, mature cysts may be found yearround, allowing a constant supply of the parasite to final hosts (Al-Kandari et al. 2007).

The large numbers of birds in summer also coincided with the highest numbers of small, uninfected snails present. Assuming a $10 \mathrm{~d}$ life span of the adult worms in the intestine of the birds, as known for other microphallids (Ginetsinskaya 1988, Fredensborg \& Poulin 2005, Mouritsen et al. 2005), recruitment of parasite eggs into the environment should also occur predominately during this period. Moreover, due to the temperature dependence of snail activity and thus foraging, it is also highly likely that most snails would acquire new infections through the ingestion of parasite eggs during this time. This further indicates that the continuation of the entire
Maritrema novaezealandensis life cycle is accelerated during warmer months and slowed if not halted during colder months. However, in addition to the various components of the life cycle studied, linking the presence of definitive hosts, effects of the parasite on birds, the fate of the parasite eggs expelled by the birds and parasite recruitment into the first intermediate snail population present major challenges for future investigations. Also, the range of bird species serving as definitive hosts for the parasite studied here remains to be identified.

\section{Temperature}

Temperature is probably the most important abiotic factor affecting parasite transmission dynamics, including many aspects of the complex life cycle of Maritrema novaezealandensis (Studer et al. 2010). Detailed thermal conditions in a microhabitat, such as soft-sediment tide pools, over long periods of time have rarely been quantified and thus provide a highly valuable data set for general dynamics of thermal conditions on temperate mudflats. The estimated transmission pressure was highly seasonal, in accordance with expectations based on available knowledge of temperature effects (e.g. Mouritsen \& Jensen 1997, Fingerut et al. 2003, Al-Kandari et al. 2007, Studer et al. 2010), and complemented the results found in the present study, clearly supporting the inferences made. Given the short lifespan of cercariae $(<24 \mathrm{~h})$, the timing of emergence is crucial and should be optimised to enhance the probability of successful transmission to the next host. The higher density of amphipods in summer also means that the more abundant cercariae are taken up by a larger number of suitable hosts, resulting in a substantial increase in metacercariae density (Table 2). Moreover, the higher temperatures during summer would also benefit the maturation of the metacercariae in crustacean hosts (Studer et al. 2010). This provides further support for the assumption of an accelerated completion of the life cycle of $M$. novaezealandensis during warmer months.

However, this also raises the issue of an increased risk of parasite-induced mortality for second intermediate crustacean hosts, in particular amphipods, under conditions where repeated massive releases of cercariae from first intermediate snail hosts occur. Infection-intensity-dependent mortality coupled with temperature-driven cercarial output can induce mortality in amphipod hosts, potentially reaching epizootic levels and increasing the risk of local extinc- 
tion (e.g. Mouritsen \& Jensen 1997). The potential of Maritrema novaezealandensis to induce intensitydependent mortality in these amphipods has been shown experimentally and inferred from field data (Fredensborg et al. 2004b, Bates et al. 2010). Consistent with the results of Fredensborg et al. (2004b), prevalence and infection intensity both increased with increasing amphipod size. Moreover, larger size classes and thus reproductively active amphipods were absent from summer samples in our study. Large amphipods are therefore considered to be most at risk of parasite-induced mortality because they accumulate parasites throughout their life time, and repeated bursts of cercariae during warmer seasons are most likely to cause mortality because they eventually surpass the tolerable infection threshold (see also Bates et al. 2010). Despite these high infection levels, the density of amphipods was still highest during summer and hence did not indicate any substantial impact of the parasite, or of predation by bird definitive hosts or other organisms, on the amphipod population. Under normal conditions, $M$. novaezealandensis is not expected to exert a strong influence on amphipod population dynamics, and thus, induced mortality is considered compensatory, i.e. larger amphipods would die regardless of the increased impact of the parasite (Fredensborg et al. 2004b). However, massive infection events (i.e. unusually high cercarial densities) under exceptional circumstances, such as heat waves, are likely and may lead to unusual mortalities. The additional direct negative effect of high temperatures on amphipod survival (Studer et al. 2010) may also contribute to such mortality events.

This risk is particularly pronounced for amphipods inhabiting mid- to upper shore areas (Bates et al. 2010). Amphipods at low shore heights, not considered in the present study, should have a much lower risk and thus may function as a source for the upper shore component of the population of a particular mudflat. Such within-mudflat dynamics, however, remain to be investigated. Similarly, for mudflats with lower levels of infection in their snail population or very low density of infected snails, this risk is likely much less pronounced. Such small- and largescale spatial variations are of major importance for the local consequences of the interactive effects between parasitism and environmental conditions on affected host populations. Thus, identifying areas with high infection levels is crucial for identifying areas at risk of parasite-induced mortality events, especially in second intermediate invertebrate host populations (e.g. Jensen \& Mouritsen 1992, Thieltges
2006). This may be the case for any comparable hostparasite system in intertidal habitats because many potential host species may already live close to their thermal tolerance limits (Helmuth et al. 2006, Hofmann \& Todgham 2010).

In conclusion, seasonal patterns were described for all of the hosts involved in the complex life cycle of the intertidal trematode Maritrema novaezealandensis. The observed patterns suggested that all of the transmission processes of $M$. novaezealandensis take place mainly during warmer months, especially the transmission from first to second intermediate hosts. The results described here provide important insights into the temporal variation of parasitism in a natural host community, providing data on first, second intermediate and definitive hosts as well as on thermal conditions experienced in the actual microhabitat where transmission occurs. It must be emphasised that areas with a high prevalence in first intermediate hosts should be considered high-risk areas for intensity-dependent mortality in second intermediate hosts. This is of great concern in the context of on-going and predicted global warming.

Acknowledgements. We thank the anonymous reviewers for their very helpful comments, which substantially improved the manuscript. We are also grateful to D. Thieltges and A. Koehler for their comments on an earlier version of this manuscript. We also thank A. Koehler and A. Bates for contributing bird count data. This research was funded by the University of Otago, New Zealand, including a Postgraduate Publishing Bursary for the preparation of this manuscript, and the Department of Zoology for postgraduate research by A.S.

\section{LITERATURE CITED}

Al-Kandari WY, Abdul-Salam J, Meakins R (2000) Temporal variations in the infection of a population of Cerithidea cingulata by larval trematodes in Kuwait Bay. J Helminthol 74:17-22

Al-Kandari MA, Abdul-Salam JM, Moussa MA, Sreelatha BS (2007) Seasonal dynamics of the cercarial and metacercarial stages of the microphallid trematode Maritrema eroliae (Digenea: Microphallidae). Acta Zool Sin 53: 463-469

Altizer S, Dobson A, Hosseini P, Hudson P, Pascual M, Rohani P (2006) Seasonality and the dynamics of infectious diseases. Ecol Lett 9:467-484

> Bates AE, Poulin R, Lamare MD (2010) Spatial variation in parasite-induced mortality in an amphipod: shore height versus exposure history. Oecologia 163:651-659

Byers JE, Blakeslee AMH, Linder E, Cooper AB, Maguire TJ (2008) Controls of spatial variation in the prevalence of trematode parasites infecting a marine snail. Ecology 89: 439-451

> Cattadori IM, Haydon DT, Hudson PJ (2005) Parasites and climate synchronize red grouse populations. Nature 433: $737-741$ 
Curtis LA, Hubbard KM (1990) Trematode infections in a gastropod host misrepresented by observing shed cercariae. J Exp Mar Biol Ecol 143:131-137

Fingerut JT, Zimmer CA, Zimmer RK (2003) Patterns and processes of larval emergence in an estuarine parasite system. Biol Bull 205:110-120

Fredensborg BL, Poulin R (2005) In vitro cultivation of Maritrema novaezealandensis (Microphallidae): the effect of culture medium on excystation, survival and egg production. Parasitol Res 95:310-313

Fredensborg BL, Poulin R (2006) Parasitism shaping host life-history evolution: adaptive responses in a marine gastropod to infection by trematodes. J Anim Ecol 75: 44-53

> Fredensborg BL, Latham AD, Poulin R (2004a) New records of gastrointestinal helminths from the red-billed gull (Larus novaehollandiae scopulinus). NZ J Zool 31:75-80

- Fredensborg BL, Mouritsen KN, Poulin R (2004b) Intensitydependent mortality of Paracalliope novizealandiae (Amphipoda: Crustacea) infected by a trematode: experimental infections and field observations. J Exp Mar Biol Ecol 311:253-265

> Fredensborg BL, Mouritsen KN, Poulin R (2005) Impact of trematodes on host survival and population density in the intertidal gastropod Zeacumantus subcarinatus. Mar Ecol Prog Ser 290:109-117

> Fredensborg BL, Mouritsen KN, Poulin R (2006) Relating bird host distribution and spatial heterogeneity in trematode infections in an intertidal snail — from small to large scale. Mar Biol 149:275-283

Ginetsinskaya TA (1988) Trematodes, their life cycles, biology and evolution. Amerind Publishing, New Delhi

> Harvell CD, Mitchell CE, Ward JR, Altizer S, Dobson AP, Ostfeld RS, Samuel MD (2002) Climate warming and disease risks for terrestrial and marine biota. Science 296: 2158-2162

> Hechinger RF, Lafferty KD (2005) Host diversity begets parasite diversity: bird final hosts and trematodes in snail intermediate hosts. Proc R Soc B 272:1059-1066

> Hechinger RF, Lafferty KD, Mancini FT, Warner RR, Kuris AM (2009) How large is the hand in the puppet? Ecological and evolutionary factors affecting body mass of 15 trematode parasitic castrators in their snail host. Evol Ecol 23:651-667

> Helmuth B, Mieszkowska N, Moore P, Hawkins SJ (2006) Living on the edge of two changing worlds: forecasting the responses of rocky intertidal ecosystems to climate change. Annu Rev Ecol Evol Syst 37:373-404

Hofmann GE, Todgham AE (2010) Living in the now: physiological mechanisms to tolerate a rapidly changing environment. Annu Rev Physiol 72:127-145

Hughes RN, Answer P (1982) Growth, spawning and trematode infection of Littorina littorea (L) from an exposed shore in North Wales. J Molluscan Stud 48:321-330

> Jensen KT, Mouritsen KN (1992) Mass mortality in two common soft-bottom invertebrates, Hydrobia ulvae and Corophium volutator - the possible role of trematodes. Helgol Meersunters 46:329-339

> Jensen KT, Ferreira SM, Pardal MA (2004) Trematodes in a Cyathura carinata population from a temperate intertidal estuary: infection patterns and impact on host. J Mar Biol Assoc UK 84:1151-1158

Keeney DB, Waters JM, Poulin R (2007) Diversity of trematode genetic clones within amphipods and the timing of same-clone infections. Int J Parasitol 37:351-357
Kim K, Dobson AP, Gulland FMD, Harvell CD (2005) Diseases and the conservation of marine biodiversity. In: Norse EA, Crowder LB (eds) Marine conservation biology: the science of maintaining the sea's biodiversity. Island Press, Washington DC, p 149-166

Koehler AV, Poulin R (2010) Host partitioning by parasites in an intertidal crustacean community. J Parasitol 96: 862-868

Kube J, Kube S, Dierschke V (2002a) Spatial and temporal variations in the trematode component community of the mudsnail Hydrobia ventrosa in relation to the occurrence of waterfowl as definitive hosts. J Parasitol 88:1075-1086

Kube S, Kube J, Bick A (2002b) Component community of larval trematodes in the mudsnail Hydrobia ventrosa: temporal variations in prevalence in relation to host life history. J Parasitol 88:730-737

- Kuris AM, Hechinger RF, Shaw JC, Whitney KL and others (2008) Ecosystem energetic implications of parasite and free-living biomass in three estuaries. Nature 454: $515-518$

Kutz SJ, Hoberg EP, Polley L, Jenkins EJ (2005) Global warming is changing the dynamics of Arctic host-parasite systems. Proc R Soc B 272:2571-2576

Lafferty KD (1993) Effects of parasitic castration on growth, reproduction and population dynamics of the marine snail Cerithidea californica. Mar Ecol Prog Ser 96: 229-237

Latham ADM, Poulin R (2003) Spatiotemporal heterogeneity in recruitment of larval parasites to shore crab intermediate hosts: the influence of shorebird definitive hosts. Can J Zool 81:1282-1291

- Lauckner G (1984) Impact of trematode parasitism on the fauna of a North Sea tidal flat. Helgol Meeresunters 37 : 185-199

> Lauckner G (1987) Ecological effects of larval trematode infestation on littoral marine invertebrate populations. Int J Parasitol 17:391-398

> Martorelli SR, Fredensborg BL, Mouritsen KN, Poulin R (2004) Description and proposed life cycle of Maritrema novaezealandensis n. sp (Microphallidae) parasitic in red-billed gulls, Larus novaehollandiae scopulinus, from Otago Harbor, South Island, New Zealand. J Parasitol 90: 272-277

Martorelli SR, Poulin R, Mouritsen KN (2006) A new cercaria and metacercaria of Acanthoparyphium (Echinostomatidae) found in an intertidal snail Zeacumantus subcarinatus (Batillaridae) from New Zealand. Parasitol Int 55: 163-167

Martorelli SR, Fredensborg BL, Leung TLF, Poulin R (2008) Four trematode cercariae from the New Zealand intertidal snail Zeacumantus subcarinatus (Batillariidae). NZ J Zool 35:73-84

McClatchie S, Jillett JB, Gerring P (1991) Observations of gulls foraging on beach-stranded plankton in Otago Harbor, New Zealand. Limnol Oceanogr 36:1195-1200

McDaniel SJ (1969) Littorina littorea: lowered heat tolerance due to Cryptocotyle lingua. Exp Parasitol 25:13-15

> Meißner K, Bick A (1997) Population dynamics and ecoparasitological surveys of Corophium volutator in coastal waters in the Bay of Mecklenburg (southern Baltic Sea). Dis Aquat Org 29:169-179

> Mouritsen KN, Jensen KT (1997) Parasite transmission between soft-bottom invertebrates: temperature mediated infection rates and mortality in Corophium volutator. Mar Ecol Prog Ser 151:123-134 
Mouritsen KN, Poulin R (2002a) Parasitism, climate oscillations and the structure of natural communities. Oikos 97: $462-468$

Mouritsen KN, Poulin R (2002b) Parasitism, community structure and biodiversity in intertidal ecosystems. Parasitology 124:S101-S117

Mouritsen KN, Poulin R (2010) Parasitism as a determinant of community structure on intertidal flats. Mar Biol 157: 201-213

Mouritsen KN, Jensen T, Jensen KT (1997) Parasites on an intertidal Corophium-bed: factors determining the phenology of microphallid trematodes in the intermediate host populations of the mud-snail Hydrobia ulvae and the amphipod Corophium volutator. Hydrobiologia 355: $61-70$

Mouritsen KN, Tompkins DM, Poulin R (2005) Climate warming may cause a parasite-induced collapse in coastal amphipod populations. Oecologia 146:476-483

Shaw DJ, Dobson AP (1995) Patterns of macroparasite abundance and aggregation in wildlife populations: a quantitative review. Parasitology 111:S111-S133

Sindermann CJ (1960) Ecological studies of marine dermatitis producing schistosome larvae in northern New England. Ecology 41:678-684

Sindermann C, Farrin AE (1962) Ecological studies of Cryptocotyle lingua (Trematoda Heterophyidae) whose larvae cause pigment spots of marine fish. Ecology 43: 69-75

Smith NF (2001) Spatial heterogeneity in recruitment of larval trematodes to snail intermediate hosts. Oecologia 127:115-122

Editorial responsibility: Hans Heinrich Janssen, Oldendorf/Luhe, Germany
Smith NF (2007) Associations between shorebird abundance and parasites in the sand crab, Emerita analoga, along the California coast. J Parasitol 93:265-273

Sousa WP (1991) Can models of soft-sediment community structure be complete without parasites? Am Zool 31: 821-830

Sousa WP, Gleason M (1989) Does parasitic infection compromise host survival under extreme environmental conditions? The case for Cerithidea californica (Gastropoda, Prosobranchia). Oecologia 80:456-464

Studer A, Thieltges DW, Poulin R (2010) Parasites and global warming: net effects of temperature on an intertidal host-parasite system. Mar Ecol Prog Ser 415:11-22

Tallmark B, Norrgren G (1976) The influence of parasitic trematodes on the ecology of Nassarius reticulatus in Gullmar Fjord Sweden. Zoon 4:149-156

Thieltges DW (2006) Parasite induced summer mortality in the cockle Cerastoderma edule by the trematode Gymnophallus choledochus. Hydrobiologia 559:455-461

Thompson RM, Mouritsen KN, Poulin R (2005) Importance of parasites and their life cycle characteristics in determining the structure of a large marine food web. J Anim Ecol 74:77-85

Wilson K, Bjornstad ON, Dobson AP, Merler S and others (2002) Heterogeneities in macroparasite infections: patterns and processes. In: Hudson PJ, Rizzoli A, Grenfell BT, Heesterbeek H, Dobson AP (eds) The ecology of wildlife disease. Oxford University Press, Oxford, p 6-44

Wood CL, Byers JE, Cottingham KL, Altman I, Donahue MJ, Blakeslee AMH (2007) Parasites alter community structure. Proc Natl Acad Sci USA 104:9335-9339

Submitted: August 24, 2011; Accepted: February 13, 2012 Proofs received from author(s): May 6, 2012 